\title{
Utilization of organic fertilisers a potential approaches for agronomic crops: A review
}

\author{
Tahir Dalorima ${ }^{1}$, Siti Zaharah Sakimin ${ }^{2} \&$ Ramisah Mohd Shah ${ }^{1 *}$ \\ ${ }^{1}$ Laboratory of Crop Science Faculty of Fisheries and Food Science, Universiti Malaysia Terengganu, Kuala Nerus, 21030 Terengganu, Malaysia \\ ${ }^{2}$ Department of Crop Science, Faculty of Agriculture, Universiti Putra Malaysia, 43400 Serdang, Selangor, Malaysia \\ *Email: ramisah@umt.edu.my
}

\section{ARTICLE HISTORY}

Received: 01 December 2020

Accepted: 02 January 2021

Published: 08 February 2021

\section{KEYWORDS}

Organic fertilizers

Crops

Poultry

Cow dung

Goat manure

Vermicompost

Growth

Yield

\begin{abstract}
Organic fertilisers are of biological origin and the amount of nutrients they produce varies greatly. Besides providing the essential macro and micro nutrients, they also provide an array of plant growthpromoting substances. Organic agronomy is a relatively recent technique of farming in developed countries. While several studies were conducted on the impact of organic fertilisers on soil properties and crop production, further research is needed to determine comparative results between organic fertilisers. This paper aims to review some of the influences and impacts of poultry manure, cow dung, goat manure, vermicomposter and seaweed extracts. Much-needed characteristics of numerous crops were enhanced with the appropriate application of these organic fertilisers. Organic fertilizer applications influences the increase of plant heights, vegetative growth, yields and yield attributes. The application of adequate fertilisers also influences the qualitative parameters and post-harvest traits of most crops. Selecting the best organic fertilisers at an optimal application rate that could be the best source of nutrient supplement in cultivating qualitative crops, is a gap that needs to bridge. Therefore, different application rates of the above organic fertilisers were also studied.
\end{abstract}

\section{Introduction}

Organic fertilisers increase the yield and quality of crops when used appropriately. Nitrogen $(\mathrm{N})$, phosphorus $\left(\mathrm{P}_{2} \mathrm{O}_{5}\right)$, potassium $\left(\mathrm{K}_{2} \mathrm{O}\right)$, sulfur $(\mathrm{S})$, copper $(\mathrm{Cu})$, calcium $(\mathrm{CaO})$, manganese $(\mathrm{Mn})$, magnesium (MgO), boron (B) and iron (Fe), zinc ( $\mathrm{Zn})$ may be a valuable source of crop nutrients, animal manure provides much of the nutrients that crops need (1). An important difference between animal manure and conventional synthetic fertilisers is that some organic nutrients in manure tend to take some time to decomposition (mineralization) and be transferred to organic form available for plant uptake. Fertilisers from animal products are slower in supply of plant nutrients than synthetic fertilisers (2). Organic fertilisers offer significant improvements in crop growth and yield, there serve as nutrient reservoir during mineralization and humification, macro and micro nutrients are released to provide the essential elements for plant growth (3). To reliably increase the yields of horticultural crops such as eggplants
(Solanum melongena), peppers (Capsicum annum L.) and tomatoes (Lycopersicon esculentum), the application of organic fertilisers has been reported (4). As observed in organic fertilisers, nitrogen availability affects vegetative improvement and promises significant and vigorous growth (5).

\section{Effects of poultry manure on crops}

There is a global organic farming trend; poultry manure as an inorganic fertiliser alternative would help achieve this target (6). The poultry manure was abundant in nutrients (Supplementary Table 1), which influences agronomic crops and ensures safe and vigorous growth. To reliably improve the yields of horticultural crops such as potato (Solanum tuberosum) (7), maize (Zea mays) (8) and tomato ( $L$. esculentum) (9), the application of poultry manure has been promising. Poultry manure had a positive impact on growth and as well as yield of pumpkin (Telfaiaria occidentalis). This may be attributed to the fact that poultry fertiliser contained important nutrient

(C) Dalorima et al (2021). This is an open-access article distributed under the terms of the Creative Commons Attribution License, which permits unrestricted use, distribution and reproduction in any medium, provided the original author and source are credited (https://creativecommons.org/licenses/by/4.0/).

To cite this article: Dalorima T, Sakimin S Z, Shah R M. Utilization of organic fertilisers a potential approaches for agronomic crops: A review. Plant Science Today. 2021;8(1):190-196. https://doi.org/10.14719/pst.2021.8.1.1045 
components linked to elevate the photosynthetic activities of crops which encourages root and vegetative development (10).

The highest yields of pepper ( $C$. annum) were achieved with the application of poultry manure at 5 t/ha (5). A study observed that tomato (L. esculentum) dry matter content, yield and soil nutrients absorption were substantially improved by poultry manure (12). Applying $25 \mathrm{t} /$ ha of poultry manure is recommended for optimizing tomato fruit yield, increasing of poultry manure application to $50 \mathrm{t} / \mathrm{ha}$ of manure did not result into fruit yield as compared with the $25 \mathrm{t} /$ ha of poultry manure. This could be so because of the dilution impact of excess organic matter and high nitrogen supply (13). High nitrogen concentration decreased calcium in leaves of tomato crops and increased tomato fruit blossom-end rot in Guyana (14).

Due to an increased $\mathrm{N}$ application, an improvement in the number of fruits and fruit size of tomato plant was observed (15). Poultry manure has significant effects on the plant's vegetative growth and ensures stable and robust production (5). There was an increase in growth with increased rates of poultry fertiliser (16). Application with an increase in poultry fertiliser rates, yield increases indicating that poultry manure provides nutrients that promote vigorous plant growth, culminating in an increase in fruit yield (6). In order to increase eggplant's yield, the use of poultry manure which is a major source nitrogen was applied to the crop at the rate of $30 \mathrm{t} / \mathrm{ha}$ (16). Relative to other manures, poultry manure contains higher nitrogen and phosphorus (17), while poultry droppings provides phosphorus more quickly than other organic waste (18). Studies have shown that poultry manure application rates at $4 \mathrm{t} / \mathrm{ha}-30 \mathrm{t} /$ ha was found be effective depending on the target crop (Supplementary Table 2).

\section{Effects of cow dung on crops}

Cow dung manure is a composted form of cattle dung with agricultural residue. It improves the soil nutrients, tilth, aeration and water holding capacity (33). Cow manure slowly and gradually releases nutrients and stimulates microbial biomass in soils (34). In India cow dung manure is the most commonly used organic manure, which contains 0.5 $0.7 \%$ N, $0.3-0.9 \%$ P205 and $0.4-1.0 \%$ K, depending upon the type of animals and nature of feed (35). To optimize fruit production and vegetative growth of agronomic crops, cow dung is recommended (36). The three essential plant nutrients, nitrogen, phosphorus and potassium (NPK), as well as several macro nutrients such as $\mathrm{Ca}, \mathrm{B}, \mathrm{Cu}, \mathrm{Mn}, \mathrm{Mg}, \mathrm{S}$, Zn etc. (Supplementary Table 3), are found in cow manure (37). Cowdung fertiliser decreases the occurrence of diseases caused by plant pathogens especially the nematodes (38).

Highest plant height, dry weight, leaf area index and yield of sweet maize was obtained under cow manure treatments (40). In sweet basil (Ocimum basilicum), application of farm yard manure and urea enhanced number of leaves and herbage yield over control and other treatments (41). The use of cow dung manure has greatly affected the length, girth, weight per plant and fruit weight per hectare of cucumber (Cucumis sativus). Similarly, it was recorded that highest weight of plant and yield per hectare in cucumber, with the application of $10 \mathrm{t} / \mathrm{ha}$ farmyard manure and $400 \mathrm{~kg} / \mathrm{ha}$ of chemical fertilisers (42). In addition to the application of farmyard manure, soil enrichment with organic matter through cow dung manure substantially improved tuberous root yield components of sweet potato (Ipomoea batatas) (43). There is a significant increase in the yield of different vegetable crops (44) and other agronomic crops with differences in the application rates of cowdung ( Supplementary Table 4). Combined application of neem cake and cow dung increased the tomato yield (45).

\section{Effects of vermicompost on crop growth}

The presence of humic acid (54) and micro and macro nutrients (55) in vermicompost fertilisers ( Supplementary Table 5) influences plant growth and development treated with the compost. The maximal increase in the plant height of Matricaria chamomilla (56) was detected when plant was treated with vermicompost. Compared with the control when cultivated in vermicompost modified peat moss supplemented with different mycorrhiza concentrations, the plant height of the maize (Zea mays) (57) increased significantly. The highest potato (S. tuberosum) plant height was observed when vermicompost was added to the soil mixed with $100 \%$ NPK (chemical fertilisers) (58). Compared to untreated (sole soil), perithecium weed prepared vermicompostimproved the plant height of Okra and the soil improved with the prescribed amount of inorganic fertilisers (59). There was an increase in the plant height of Crossandra (Crossandra undulaefolia) in plots treated vermicompost as opposed to the control plots (60). Vermicompost application increased eggplant (S. melongena) plant height (61). Greenhouse spinach treated vermicompost produces the high value in plant height and number of leaves in treatment with highest application rates (62).

It was reported that, vermicompost treatments significantly increased plant height relative to control treatments, no substantial difference between vermicompost treatments and chemical fertilisers treatment was observed (64). The average plant height of the Amaranthus species increased with the application of vermicompost. The average plant height and number of branches had a higher values than control and treatment with inorganic fertiliser application after 30 days of germination. A study on vermicompost, cowdung, vermiwash and inorganic fertilisers application on okra (Abelmoschus esculentus), reveals that vermiwash and vermicompost had great influence on the growth and yield of okra (65). Additionally in several studies it was reported that, application of vermicompost gave a significant yield in $A$. esculentus (66), strawberry (Fragaria $x$ ananassa) yields (67), fruit yield of eggplant (Solanum melongena L.) (61). Moreso, treatments with vermicompost influences potato (Solanum tuberosum) production yield (58), total yield of cucumber (C. sativus) (68), harvest index in Crossandra (C. undulaefolia) (60), higher tomato ( $L$. esculentum) yield (55), Geranium oil yields in 
Pelargonium species (69) and Matricaria chamomilla (56). Several studies in Supplementary Table 6 shows the effects of vermicompost application rates on crops.

\section{Effects of goat dung on crop growth}

Like other animal manures, goat manure has essential elements (Supplementary Table 7) required for plant growth including nitrogen, though such composition may vary geographically depending on the diet that goats feed on (81). Compared to other animal manures, goat manure has been shown to release high concentrations of plant required nutrients more than cattle manure, horse manure and others for except poultry manure (82). Even though animal manure varies in nitrogen content due to the type of feed given to animals, generally total nitrogen content in goat manure, for example, is about $2-3 \%$ of dry weight manure. The total nitrogen requires to be processed to get plant-available nitrogen (nitrate, ammonium), of which mineralizable nitrogen is about $20 \%$ of total nitrogen (83).

Goat manure can be treated before being added to the soil, in soil-based agriculture, or applied directly to the soil so that microorganisms in the soil will break the manure naturally in the soil. This is because, the transfer of nutrients from organic to inorganic (plant-available) particularly the nitrogen becomes available through mineralization. The availability of phosphorus from manure is also high in addition to nitrogen (more than 70\%) since much of the $\mathrm{P}$ is inorganic and readily accessible (81). Nitrogen mineralization is related to the ease with which microorganisms break down the carbon in the manures. Nitrogen available from manures depends on the nitrogen content and the stability of the nitrogen or the ease with which it is mineralized. Aged manures lose nitrogen by volatilization of ammonia; the remaining nitrogen is more stable or resistant to mineralization (84). Therefore, it is advisable to work with manure that is not too aged or composted since the composting process produces lower nitrogen from goat manure, therefore, spreading the manure and combining it with the soil as soon as possible is the perfect manure management to maximize nitrogen supply. The longer the time between production and incorporation, the lower the available nitrogen (84).

Goat manure world-wide has been applied directly to the soil where it was processed to avail plant required nutrients (86). For example, In Sri Lanka, the direct addition of goat manure to the soil for coconut plantation resulted in the supply of sufficient plant nutrients needed for the coconut plantation such that there was a significant increase in nut yield (87). In an organically managed field trial, in the United States of America, it was observed that in a raw dairy goat manure treatment, the yield of corn was still higher over a three-year cycle relative to a compost of dairy goat manure and leaves (88). Elsewhere in Kenya, goat manure applied directly to the soil helped provide nutrients (89), and helped reduce soil acidity, which inturn aids in crop production (90). Goat manure was effective at applying $5 \mathrm{t} / \mathrm{ha}$ to high dose of $40 \mathrm{t} / \mathrm{ha}$ (Supplementary Table 8).

\section{Effects of seaweeds on crop growth}

An important part of coastal marine habitats is marine algae. These include the macroscopic, multicellular marine algae usually found in the world's oceans costal areas where there are appropriate substrates. On the rocky shores of the temperate regions, brown seaweeds are the second most common group of about 2000 species that surpass their maximum biomass levels. They are the type most widely used in agriculture (96), and Ascophyllum nodosum (Brown seaweed) (97) is the most researched among them, due to its high mineral composition (Supplementary Table 9). Besides $A$. nodosum, other brown algae include, Turbinaria spp, Sargassum spp. Laminaria spp. and Fucus spp. In agriculture, they are used as biostimulants (98). The benefits of seaweeds as a source of organic manure and fertilisers have contributed to soil modification for years (99).

Nearly 15 metric tons of seaweed's fertilisers are produced yearly (100), of which a large proportion is used to improve crop growth and yield as nutritional enhancements and as biostimulants or biofertilisers. For use in agriculture and horticulture, a range of commercial seaweed extract products are available. The application of seaweed extract has a wide range of beneficial effects on plants, such as early germination and seed establishment, improved crop production and yield, increased resistance to biotic and abiotic stress, and increased post-harvest qualities of crops (101).

Different beneficial effects of both extracts and suspensions of marine brown algae are used in agronomy and agriculture (103). Algal extracts increase seed germination, boost plant growth, yield, flower set and development of fruit and post-harvest shelf life as plant growth biostimulants (104).

Results of marigold experiments show that, vegetative growth was increased by using seaweed extract (105). The improvement in seaweed treated crops growth could be attributed to the presence of macro and micronutrients and some growthpromoting compounds in the extract of seaweed (103). Kentucky bluegrass (106), tall fescue and creeping bentgrass have also been shown to increase antioxidant status through exogenous application of seaweed extract (107). Seaweed extracts collected from Ecklonia maxima have increased the amount of vegetables per plant when added to soil drench as fertiliser in lettuce leaf (108) and wheat (109). Seaweeds have growth-enhancing ability this may be due to the presence of macro and micro nutrients available in seaweeds (110). Application to soils or tomato foliage a low concentration of $A$. nodosum extract produces a higher chlorophyll level than untreated controls (111). The fresh weight of green gram seedlings tested with seaweed extracts steadily increased the growth of Vigna unguiculata promoted by increasing concentration of seaweed extract from Ulva lactuca (112), similar effects were also reported in red gram (113), in cowpea (114) and green gram, 
which reported linear growth of both shoots and roots. In various plant systems, effects of $A$. nodosum have been identified, including the increase of plant growth (115).

\section{Conclusion and prospects of organic fertilisers}

In conclusion, organic fertilisers response has a significant role in the growth and yield parameter of different tested crops. Organic fertilisers are widely applied in crop production, and they are proper substitutions for chemical fertilisers. Application of bio-fertiliser significantly improved quality and quantity features in agronomic crops. Organic farming is not necessarily non-chemical agriculture, but it is a method that combines soil, plant and water relationships. Organic agriculture contributes to soil conservation, fair energy exchange in soil, seeds, water environment processes, maintains the ecological life cycle intact and helps retain massive yield levels. The application of organic fertilisers at appropriate rates gives the maximum yield of crops. In contrast to synthetic fertilisers, organic fertilisers significantly impact plant height, fresh flower weight, branch number, increase soil property and microbial activity in the soil and a long lasting supply of macro and micro nutrients.

As organic farming continues to expand globally, to support the yield and growth of organic crops as a whole, organic fertilisers such as farmyard manures are required. Improving the current technology to increase fertiliser production in terms of nutrients supply and use of locally available organic resources is the future of organic farming. Because of its high price relative to synthetic fertilizer, farmers current use of organic fertilizer is still poor. There are also some challenges to the use of organic fertilisers that are not overcome: for example, a lack of expertise and experience in the use of organic fertilising; poor capacity to respond on unpredicted external factors such as drought, sudden emergence of new diseases and pests and high certification costs amongst others (116).

Therefore, more research is required to resolve the concerns of farmers. For example, creative and efficient agricultural services programmes could be introduced to inform and support farmers in organic mechanics to resolve the inadequate expertise and experience in the management of an organic farming system (117). The studies mentioned in the article identified the use of several organic fertilisers. These systems have proved successful and can improve farmers profitability. The lack of economic analysis on these organic fertilisers leads to the recommendation of more studies or long-term evaluation of the economic viability of these organic fertilisers.

\section{Acknowledgements}

We are grateful to the Post Graduate Student Incentive Scheme (PSIS), Centre for Academic Management and Quality, Universiti Malaysia Terengganu.

\section{Authors' contributions}

All authors contributed equally for the development of this manuscript.

\section{Conflict of interests}

The authors declares no conflict of interest.

\section{Supplementary files}

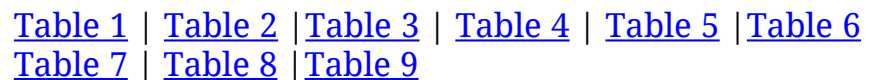

\section{References}

1. Fageria NK. The use of nutrients in crop plants. CRC press; 2016. https://doi.org/10.1201/9781420075113

2. Motsenbocker CE, Arancibia RA. In-row spacing influences triploid watermelon yield and crop value. Horttechnology. 2002;12(3):437-40. https://doi.org/10.21273/HORTTECH.12.3.437

3. Chiezey UF, Odunze C. Soybean response to application of poultry manure and phosphorus fertilizer in the sub-humid savanna of Nigeria. J Ecol Nat Environ . 2009;1(2):25-31.

4. Górecki RS, Górecki MT. Utilization of waste wool as substrate amendment in pot cultivation of tomato, sweet pepper and eggplant. Polish J Environ Stud. 2010;19(5):1083-37.

5. Aliyu L. Effect of organic and mineral fertilizers on growth, yield and composition of pepper (Capsicum annuum L.) Biol Agric Hortic. 2000;18(1):29-36. https://doi.org/10.1080/01448765.2000.9754862

6. Dauda SN, Ajayi FA, Ndor E. Growth and yield of water melon (Citrullus lanatus) as affected by poultry manure application. Electron J Environ Agric Food Chem. 2009;8(4):305-11.

7. Oustani M, Halilat M, Chenchouni H. Effect of poultry manure on the yield and nutriments uptake of potato under saline conditions of arid regions. Emirates J Food Agric. 2015;27(1):106-20. https://doi.org/10.9755/ejfa.v27i1.17971

8. Boateng SA, Zickermann J, Kornahrens M. Poultry manure effect on growth and yield of maize. West African J Appl Ecol 2006;9(1):1-11. https://doi.org/10.4314/wajae.v9i1.45682

9. Adekiya AO, Agbede TM. Growth and yield of tomato (Lycopersicon esculentum) as influenced by poultry manure and NPK fertilizer from 1000-1240 mm. The type of soil is Alfiso classified as Oxic Tropuldalf (USDA) or Luvisol (FAO). 2009; 21(1):10-20. https://doi.org/10.9755/ejfa.v21i1.5154

10. Shiyam JO, Binang WB. Effect of poultry manure and plant population on productivity of fluted pumpkin (Telfaiaria occidentalis F.) in Calabar, Nigeria. J Org Syst. 2013;8(2):29-35

11. Yaldız G, Çamlıca M, Özen F, Eratalar SA. Effect of poultry manure on yield and nutrient composition of sweet basil (Ocimum basilicum L.). Commun Soil Sci Plant. 2019;50(7):838 52.

12. Akande MO, Adedira JA, Oluwatoyinbo FI. Effects of rock phosphate amended with poultry manure on soil available P and yield of maize and cowpea. African J Biotechnol. 2005;4(5):444-48.

13. Agbede TM, Adekiya AO. Evaluation of sweet potato ( Ipomoea batatas L.) performance and soil properties under tillage methods and poultry manure levels Ipomoea batatas) 2011;23(2):164-77. https://doi.org/10.9755/ejfa.v23i2.6454

14. Saxena MC, Yadav DS. Parallel cropping of soybean with pigeon-pea under humid sub-tropical conditions of Pantnagar. Indian J Agron. 1976;21(2):131-34.

15. Gupta A, Shukla V. Response of tomato (Lycopersicon esculentum) to plant spacing, nitrogen, phosphorus and potassium fertilization. Indian J Hortic. 1977;34(3):270-76. 
16. Dauda S, Aliyu L, Chiezey U. Effect of variety, seedling age and poultry manure on growth and yield of garden egg (Solamun gilo L.). Niger Acad Forum. 2005;9(1):88-95.

17. Khalid AA, Tuffour HO, Bonsu M. Influence of poultry manure and NPK fertilizer on hydraulic properties of a sandy soil in Ghana. Int J Sci Res Agric Sci. 2014;1(2):16-22. https://doi.org/10.12983/ijsras-2014-p0016-0022

18. Garg S, Bahl GS. Phosphorus availability to maize as influenced by organic manures and fertilizer $\mathrm{P}$ associated phosphatase activity in soils. Bioresour Technol. 2008;99(13):5773-77. https://doi.org/10.1016/j.biortech.2007.10.063

19. Ayeni LS, Adetunji MT. Integrated application of poultry manure and mineral fertilizer on soil chemical properties, nutrient uptake, yield and growth components of maize. Nat Sci. 2010;8(1):60-67.

20. Law-Ogbomo KE, Remison SU. Growth and yield of maize as influenced by sowing date and poultry manure application. Not Bot Horti Agrobot Cluj-Napoca. 2009;37(1):199-203.

21. Dauda SN, Ndor E, State N, State N. Growth and yield of watermelon (Citrullus lanatus) AS. Electron J Environ Agric Food Chem. 2009;8(4):2-8.

22. Boateng S, Zickermann J, Kornahrens M. Poultry manure effect on growth and yield of maize. West African J Appl Ecol. 2009;9(1):1-11. https://doi.org/10.4314/wajae.v9i1.45682

23. Adeleye EO, Ayeni LS, Ojeniyi SO. Effect of poultry manure on soil physico-chemical properties, leaf nutrient contents and yield of yam (Dioscorea rotundata) on Alfisol in Southwestern Nigeria. J Am Sci. 2010;6(10):871-78.

24. Oikeh SO, Asiegbu JE. Growth and yield responses of tomatoes to sources and rates of organic manures in ferralitic soils. $\begin{array}{lll}\text { Bioresour } & \text { Technol. 1993;45(1):21-25. }\end{array}$ https://doi.org/10.1016/0960-8524(93)90138-2

25. Law-Ogbomo KE, Ajayi SO. Growth and yield performance of Amaranthus cruentus influenced by planting density and poultry manure application. Not Bot Horti Agrobot ClujNapoca. 2009;37(2):195-99.

26. Saleha A. Studies on the effects of organic vs. inorganic form of nitrogen on the quality of okra. J Maharashtra Agric Univ. $1992 ; 17: 133-34$

27. Pimpini F, Giardin L, Borin M, Gianquinto G. Effects of poultry manure and mineral fertilizers on the quality of crops. J Agric Sci. 1992;118(2):215-21. https://doi.org/10.1017/S0021859600068817

28. Giardini L, Pimpini F, Borin M, Gianquinto G. Effects of poultry manure and mineral fertilizers on the yield of crops. J Agric Sci. 1992;118(2):207-13. https://doi.org/10.1017/S0021859600068805

29. Zamil SS, Quazi QF, Mah CD, Al Wahid A. Effects of different animal manures on yield quality and nutrient uptake by mustard cv. Agrani. BRAC University Journal. 2004;1(2):59-66.

30. Agyeman K, Osei-Bonsu I, Berchie JN, Osei MK, Mochiah MB, Lamptey JN. Effect of poultry manure and different combinations of inorganic fertilizers on growth and yield of four tomato varieties in Ghana. Agric Sci. 2014;2(4):27-33. https://doi.org/10.12735/as.v2i4p27

31. Haruna IM. Growth and yield of sesame (Sesamum indicum L.) as affected by poultry manure, nitrogen and phosphorus at Samaru, Nigeria. 2011;21(4):653-59.

32. Ghimire S, Nainabasti A, Sharma M, Marahatta S, Giri H. Effects of urea and poultry manure combination on yield and quality of different lettuce (Lactuca sativa L.) varieties in Chitwan, Nepal. SAARC J Agric. 2019;17(1):201-10. https://doi.org/10.3329/sja.v17i1.42773

33. Raj A, Jhariya MK, Toppo P. Cow dung for eco-friendly and sustainable productive farming. Env Sci. 2014;3(10):201-22.

34. Belay A, Claassens AS, Wehner FC, de Beer JM. Influence of residual manure on selected nutrient elements and microbial composition of soil under long-term crop rotation. South African J Plant Soil. 2001;18(1):1-6. https://doi.org/10.1080/02571862.2001.10634392

35. Chhonkar NK. Fertilizer Policy for sustainable agriculture, conference paper. Indian J Fert. 1995;23:1-2.
36. Hasan MR, Solaiman AHM. Efficacy of organic and organic fertilizer on the growth of Brassica oleracea L. (Cabbage). Int J Agric Crop Sci. 2012;4(3):128-38.

37. Fulhage $\mathrm{CD}$. Reduce environmental problems with proper land application of animal wastes. Columbia, Mo Univ Missouri. 1993.

38. Singh S, Mathur N. Biological control of root-knot nematode, Meloidogyne incognita infesting tomato. Biocontrol Sci Technol. 2010;20(8):865-74. https://doi.org/10.1080/09583157.2010.487935

39. Whalen JK, Chang C, Clayton GW, Carefoot JP. Cattle manure amendments can increase the pH of acid soils. Soil Sci Soc Am J. 2000;64(3):962-66. https://doi.org/10.2136/sssaj2000.643962x

40. Efthimiadou A, Bilalis D, Karkanis A, Froud-Williams B. Combined organic/inorganic fertilization enhance soil quality and increased yield, photosynthesis and sustainability of sweet maize crop. Aust J Crop Sci. 2010;4(9):722-79.

41. Sundharaiya K, Ponnuswamy V, Velmurugan S. Effect of FYM, sulphur and different nitrogen sources on herbage and seed yield of sweet basil (Ocimum basilicum). South Indian Hortic. 2003;51:93-95.

42. Eifediyi EK, Remison SU. Growth and yield of cucumber (Cucumis sativus L.) as influenced by farmyard manure and inorganic fertilizer. J Plant Breed Crop Sci. 2010;2(7):216-20.

43. Abdissa Y, Tekalign T, Pant LM. Growth, bulb yield and quality of onion (Allium cepa L.) as influenced by nitrogen and phosphorus fertilization on vertisol I. growth attributes, biomass production and bulb yield. African J Agric Res. 2011;6(14):3252-58

44. Raghav M, Kumar T, Kamal S. Effect of organic sources of nutrients on growth, yield and quality of potato. Progress Hortic. 2007;39(1):95-100.

45. Parray BA, Ganai AM, Fazili KM. Physico-chemical parameters and growth yield of tomato (Lycopersicum esculentum): role of farm yard manure and neem cake. Am J Agric Environ Sci. 2007;2(3):303-37.

46. Solaiman ARM, Rabbani MG. Effects of NPK and cow dung on growth and yield of tomato. Bull Inst Trop Agric Kyushu Univ. 2006;29(1):31-37.

47. Mahabub S, Khan M, Mazed H, Sarker S, Tareque M. Effect of cow manure on growth, yield and nutrient content of mungbean. Asian Res J Agric. 2016;2(1):1-6. https://doi.org/10.9734/ARJA/2016/29297

48. Damiyal D., Manggoel W, Ali S, Dalokom DY, Mashat IM. Effect of cattle manure and inorganic fertilizer on the growth and yield of hybrid maize (Zea mays L.). World Res J Agric Sci. 2017;4(1):102-10

49. Agbede T, Ojeniyi S, Adeyemo A. Effect of poultry manure on soil physical and chemical properties, growth and grain yield of sorghum in southwest, Nigeria. Am J Sustain Agric. 2008;2(1):72-77.

50. Eifediyi EK, Remison SU, Ahamefule HE, Azeez KO, Fesobi PO. Performance of watermelon (Citrullus lanatus L.) in response to organic and NPK fertilizers. Acta Univ Sapientiae, Agric Environ. 2018;9(1):5-17. https://doi.org/10.1515/ausae-2017 0001

51. Olfati JA, Khasmakhi-Sabet SA, Shabani H, Peyvast G. Alternative organic fertilizer to cow manure for french dwarf deandProduction. Int J Veg Sci. 2012;18(2):190-98. https://doi.org/10.1080/19315260.2011.606291

52. Uzoma KC. Effect of cow manure biochar on maize productivity under sandy soil condition. 2011;5(2):205-12. https://doi.org/10.1111/j.1475-2743.2011.00340.x

53. Barreto PD, Dynia JF. Monocropping systems in the Brazilian semi arid Tropics In: Earl Engene Watt and Joao Pratagil Pereira de Aranjo. Cowpea Res Brazil IITA, Ibadan Niger. 1988;

54. Arancon NQ, Edwards CA, Atiyeh R, Metzger JD. Effects of vermicomposts produced from food waste on the growth and yields of greenhouse peppers. Bioresour Technol. 2004; 93(2):139-44. https://doi.org/10.1016/j.biortech.2003.10.015

55. Atiyeh RM, Lee S, Edwards CA, Arancon NQ, Metzger JD. The influence of humic acids derived from earthworm-processed 
organic wastes on plant growth. Bioresour Technol. 2002;84(1):7-14. https://doi.org/10.1016/S0960-8524(02)00017-2

56. Hadi MRHS, Darz MT, Ghandehari Z, Riazi G. Effects of vermicompost and amino acids on the flower yield and essential oil production from Matricaria chamomile L. J Med Plant Res. 2011;5(23):5611-17.

57. Gutiérrez-Miceli FA, Moguel-Zamudio B, Abud-Archila M, Gutiérrez-Oliva VF, Dendooven L. Sheep manure vermicompost supplemented with a native diazotrophic bacteria and mycorrhizas for maize cultivation. Bioresour Technol. https://doi.org/10.1016/j.biortech.2008.01.012

58. Alam MN, Jahan MS, Ali MK, Ashraf MA, Islam MK. Effect of vermicompost and chemical fertilizers on growth, yield and yield components of potato in barind soils of Bangladesh. J Appl Sci Res. 2007;3(12):1879-88.

59. Vijaya KS, Seethalakshmi S. Response of eggplant (Solanum melongena L.) to integrated nutrient management amended soil. Int J Sci Eng Res. 2011;2(8):1-8.

60. Gajalakshmi S, Abbasi SA. Effect of the application of water hyacinth compost/vermicompost on the growth and flowering of Crossandra undulaefolia and on several vegetables. Bioresour Technol.

org/10.1016/S0960-8524(02)00096-2

61. Moraditochaee M, Bozorgi HR, Halajisani N. Effects of vermicompost application and nitrogen fertilizer rates on fruit yield and several attributes of eggplant (Solanum melongena L.) in Iran. World Appl Sci J. 2011;15(2):174-78.

62. Ayyobi H, Peyvast G-A, Olfati J-A. Effect of vermicompost and vermicompost extract on oil yield and quality of peppermint (Mentha piperita L.). J Agric Sci Belgrade. 2013;58(1):51-60. https://doi.org/10.2298/JAS1301051A

63. Sardoei AS, Roien A, Sadeghi T. Effect of vermicompost on the growth and flowering of African marigold (Tagetes erecta) Young Researchers Club, Jiroft Islamic Azad University Jiroft Branch Iran. 2014;14(7):631-35.

64. Uma B, Malathi M. Vermicompost as a soil supplement to improve growth and yield of Amaranthus species. Res J Agric Biol Sci . 2009;5(6):1054-60.

65. Ansari AA, Sukhraj K. Effect of vermiwash and vermicompost on soil parameters and productivity of okra (Abelmoschus esculentus) in Guyana. African J Agric Res. 2010;5(14):1794-98. https://doi.org/10.5897/AJAR09.107

66. Joshi R, Singh J, Vig AP. Vermicompost as an effective organic fertilizer and biocontrol agent: effect on growth, yield and quality of plants. Rev Environ Sci Biotechnol. 2014;14(1):13759. https://doi.org/10.1007/s11157-014-9347-1

67. Zuo Y, Zhang J, Zhao R, Dai H, Zhang Z. Application of vermicompost improves strawberry growth and quality through increased photosynthesis rate, free radical scavenging and soil enzymatic activity. Sci Hortic 2018;233:132-40. https:// doi.org/10.1016/j.scienta.2018.01.023

68. Azarmi R, Giglou MT, Hajieghrari B. The effect of sheepmanure vermicompost on quantitative and qualitative properties of cucumber (Cucumis sativus L.) grown in the greenhouse. 2009;8(19):4953-57.

69. Chand S, Pandey A, Anwar M, Patra DD. Influence of integrated supply of vermicompost, biofertilizer and inorganic fertilizer on productivity and quality of rose scented geranium (Pelargonium sp.). Indian J Nat Prod Resor. 2011;2:375-82.

70. Kumari MS, Ushakumari K. Effect of vermicompost enriched with rock phosphate on the yield and uptake of nutrients in cowpea (Vigna unguiculata L.). J Trop Agric. 2002;40:27-30.

71. Subedi S, Dhakal D. Economics of poultry manure as an alternative to chemical fertilizer for agricultural production in Nepal. J Inst Agric Anim Sci. 2018;268:259-68. https://doi.org/10.3126/jiaas.v33i0.20713

72. Joshi R, Vig AP. Effect of vermicompost on growth, yield and quality of tomato. Appl Sci. 2010;2:117-23.

73. Wani KA, Rao RJ. Effect of vermicompost on growth of brinjal plant (Solanum melongena) under field Conditions. J New Biol Reports. 2012;1(1):25-28.
74. Zaremanesh $\mathrm{H}$, Nasiri B, Amiri A. The effect of vermicompost biological fertilizer on corn yield. J Mater Environ Sci. 2017;8(1):154-59.

75. Makode PM. Effect of vermicompost on the growth of Indian orange, Citrus reticulatus with reference to its quality and quantity. Biosci Biotechnol Res Commun. 2015;8(2):217-20.

76. Ushakumari K, Prabhakumari P, Padmaja P. Efficiency of vermicompost on growth and yield of summer crop okra (Abelmoschus esculentus L.). Journal of Tropical Agriculture. 1999;37:87-88.

77. Singh R, Sharma RR, Kumar S, Gupta RK, Patil RT Vermicompost substitution influences growth, physiological disorders, fruit yield and quality of strawberry (Fragaria ananassa). Bioresour Technol. 2008;99(17):8507-11. https://doi.org/10.1016/j.biortech.2008.03.034

78. Zende GK, Ruikar SK, Joshi SN. Effect of application of vermicompost along with chemical fertilizers on sugarcane yield and juice quality. Indian Sugar. 1998;48(5):357-69.

79. Sallaku G, Babaj I, Kaciu S, Balliu A. The influence of vermicompost on plant growth characteristics of cucumber (Cucumis sativus L.) seedlings under saline conditions. J Food, Agric Environ. 2009;7(3-4):869-72.

80. Olle M. Short communication: The effect of vermicompost based growth substrates on tomato growth. Agraart J Agric Sci 2016;12(1):38-41.

81. Chadwick DR, John F, Pain BF, Chambers BJ, Williams J. Plant uptake of nitrogen from the organic nitrogen fraction of animal manures: A laboratory experiment. J Agric Sci 2000;134(2):159-68. https://doi.org/10.1017/S0021859699007510

82. Azeez JO, Van Averbeke W. Nitrogen mineralization potential of three animal manures applied on a sandy clay loam soil. Bioresour Technol. 2010;101(14):5645-51. https://doi.org/10.1016/j.biortech.2010.01.119

83. Muñoz GR, Kelling KA, Powell JM, Speth PE. Comparison of estimates of first-year dairy manure nitrogen availability or recovery using nitrogen-15 and other techniques. J Environ Qual. 2004;33(2):719. https://doi.org/10.2134/jeq2004.7190

84. Pratt P, Castellanos J. Available nitrogen from animal manures. Calif Agric. 1981;35(7):24.

85. Awodun MA, Omonijo LI, Ojeniyi SO. Effect of goat dung and NPK fertilizer on soil and leaf nutrient content, growth and yield of pepper. Inter J Soil Sci. 2007:142-27. https://doi.org/10.3923/ijss.2007.142.147

86. Sunaryo Y, Purnomo D, Darini MT, Cahyani VR. Nutrients content and quality of liquid fertilizer made from goa manure. J Phy Conf Ser. 2018;1022(1):012053. https://doi.org/10.1088/1742-6596/1022/1/012053

87. Tennakoon NA. Goat Manure as a soil ameliorant and yield stimulant in coconut. Cocos. 2010;8(0):26. https://doi.org/10.4038/cocos.v8i0.2120

88. Reider CR, Herdman WR, Drinkwater LE, Janke R. Yields and nutrient budgets under composts, raw dairy manure and mineral fertilizer. Compost Sci Util. 2000;8(4):328-39. https://doi.org/10.1080/1065657X.2000.10702006

89. Kihanda FM, Warren GP, Micheni AN. Effect of manure application on crop yield and soil chemical properties in a long-term field trial of semi-arid Kenya. Nutr Cycl Agroecosystems. https://doi.org/10.1007/s10705-006-9024-z

90. Harun IG, Benson EM, Benjamin OD. Effect of lime and goat manure on soil acidity and maize (Zea mays) growth parameters at Kavutiri, Embu County- Central Kenya. J Soil Sci Environ Manag. 2015;6(10):275-83. https://doi.org/10.5897/JSSEM15.0509

91. Smith MAK, Ayenigbara EA. Comparative growth and nutrient composition of Indian spinach in an enriched humid tropical environment. In: African Crop Science Conference Proceedings. 2001;1007-13.

92. Odiete I, Ojeniyi SO, Akinola OM, Achor AA. Effect of goat dung manure on soil chemical composition and yield components of okra, amaranthus and maize. In: Proceedings 25th Annua Conference of Soil Science Society of Nigeria. 1999:174-78. 
93. Awodun MA. Effect of goat manure and urea fertilizer on soil, growth and yield of okra (Abelmoschus esculentus L.). Int J Agric Res. https://doi.org/10.3923/ijar.2007.632.636

94. Uwah DF, Eyo VE. Effects of number and rate of goat manure application on soil properties, growth and yield of sweet maize (Zea mays L). Sustain Agric Res. 2014;3(4):75. https://doi.org/10.5539/sar.v3n4p75

95. Borges FRM, Bezerra FML, Marinho AB, Ramos EG, Adriano JDNJ. Goat manure fertilization and irrigation on production components of sunflower. Rev Caatinga. 2019;32(1):211-21. https://doi.org/10.1590/1983-21252019v32n121rc

96. Blunden G, Cripps AL, Gordon SM, Mason TG, Turnei CH. The characterisation and quantitative estimation of betaines in commercial seaweed extracts. Bot Mar. 1986;29(2):155-60. https://doi.org/10.1515/botm.1986.29.2.155

97. Ugarte RA, Sharp G, Moore B. Changes in the brown seaweed Ascophyllum nodosum (L.) Le Jol. plant morphology and biomass produced by cutter rake harvests in southern New Brunswick, Canada. In: Eighteenth International Seaweed Symposium. 2008.125-33. https://doi.org/10.1007/978-1-40205670-3_16

98. Hong DD, Hien HM, Son PN. Seaweeds from Vietnam used for functional food, medicine and biofertilizer. J Appl Phycol. 2007.817-26. https://doi.org/10.1007/s10811-007-9228-X

99. Temple WD, Bomke AA. Effects of kelp (Macrocystis integrifolia) on soil chemical properties and crop response. Plant Soil. 1988;105(2):213-22. https://doi.org/10.1007/BF02376785

100. Panda D, Pramanik K, Nayak BR. Use of sea weed extracts as plant growth regulators for sustainable agriculture. 2012;3(3):404-11.

101. Norrie J, Keathley JP. Benefits of Ascophyllum nodosum marine-plant extract applications to "Thompson seedless" grape production. In: Acta Horticulturae. 2006:2437.https://doi.org/10.17660/ActaHortic.2006.727.27

102. Olsson J, Toth GB, Albers E. Biochemical composition of red, green and brown seaweeds on the Swedish west coast. J Appl Phycol. 2020:23-29. https://doi.org/10.1007/s10811-020-02145-W

103. Blunden G. Agricultural uses of seaweeds and seaweed extracts. Seaweed Resour Eur. 1991;65-81.

104. Calvo P, Nelson L, Kloepper JW. Agricultural uses of plant biostimulants. Plant and Soil. 383;2014:3-41. https://doi.org/10.1007/s11104-014-2131-8

105. Russo AR. Epifauna living on sublittoral seaweeds around Cyprus. Hydrobiologia. 1997;344(1-3):169-79. https://doi.org/10.1023/A:1002970714963
106. Shukla PS, Mantin EG, Adil M, Bajpai S, Critchley AT, Prithiviraj B. Ascophyllum nodosum based biostimulants: Sustainable applications in agriculture for the stimulation of plant growth, stress tolerance, and disease management. Front Plant Sci. 2019;10:1-22. https://doi.org/10.3389/fpls.2019.00655

107. Zhang X, Schmidt RE. Hormone-containing products' impact on antioxidant status of tall fescue and creeping bentgrass subjected to drought. Crop Sci. 2000;40(5):1344-49. https://doi.org/10.2135/cropsci2000.4051344x

108. Crouch IJ, Beckett RP, van Staden J. Effect of seaweed concentrate on the growth and mineral nutrition of nutrientstressed lettuce. J Appl Phycol. 1990;2(3):269-72. https://doi.org/ 10.1007/BF02179784

109. Shah MT, Zodape ST, Chaudhary DR, Eswaran K, Chikara J. Seaweed sap as an alternative liquid fertilizer for yield and quality improvement of wheat. J Plant Nutr. 2013;36(2):192 200. https://doi.org/10.1080/01904167.2012.737886

110. Zodape ST, Kawarkhe VI, Patolia IS, Warade AD. Effect of liquid seaweed fertilizer on yield and quality of okra (Abelmoschus esculentus L.). J Sci Ind Res (India). 2008;67(12):1115-7.

111. Colla G, Cardarelli M, Bonini P, Rouphael Y. Foliar applications of protein hydrolysate, plant and seaweed extracts increase yield but differentially modulate fruit quality of greenhouse tomato. HortScience. https://doi.org/10.21273/HORTSCI12200-17

112. Jayasinghe PS, Pahlawattaarachchi V, Ranaweera KKD. Effect of seaweed liquid fertilizer on plant growth of Capsicum annum. Discovery. 2016;52(244):723-34

113. Kamaladhasan N, Subramanian SK. Influence of seaweed liquid fertilizers on legume crop, red gram. J Basic Appl Biol 2009;3(1-2):21-24.

114. Lingakumar K, Jayaprakash R, Manimuthu C, Haribaskar A. Gracilaria edulis-an effective alternative source as a growth regulator for legume crops. Seaweed Res Utiln. 2002;24(1):11723.

115. Saravanan S, Thamburaj S, Veeraragavathatham D, Subbiah A Effect of seaweed extract and chlormequat on growth and fruit yield of tomato (Lycopersicon esculentum). Indian J Agric Res. 2003;37(2):79-87.

116. Chouichom S, Yamao M. Organic fertilizer use in northeastern Thailand: an analysis of some factors affecting farmers attitudes. In: Sustainable Agricultural Development. Springer 2011:185-96. https://doi.org/10.1007/978-94-007-0519-7_13

117. Gareau SE. Economic analysis of conventional and alternative nutrient management approaches. In: Advances in Citrus Nutrition. Springer; 2012:415-24. https://doi.org/10.1007/978-94007-4171-3 27 